\title{
"Slave Mothers", Partus Sequitur Ventrem, and the Naturalization of Slave Reproduction in Nineteenth-Century Brazil
}

\author{
Martha S. Santos[1]
}

\begin{abstract}
Through an examination of slaveholders' discourses on the need to find ways to replenish the slave labor force after the 1831 legal suppression of the African trade, this article demonstrates the centrality of female slave reproduction to the most significant debates on slavery and emancipation during the nineteenth century. Through tropes and metaphors that appealed to nature, this slaveholding discourse emphasized reproduction and mothering labor as the "natural" function of enslaved women - a function that would also serve to pacify rebellious male slaves. This work also demonstrates that, within a context of intensified symbolic value of enslaved women's reproduction, slaveholders and jurists emphasized the validity of the legal device partus sequitur ventrem in order to communicate a notion of the legality of slavery, precisely at the time of increasing delegitimation of the institution, both within and outside Brazil.
\end{abstract}

Keywords: Slave mothers, partus sequitur ventrem, slave reproduction.

"Mães escravas", partus sequitur ventrem, e a naturalização da reprodução escrava no Brasil oitocentista.

\section{Resumo}

Tomando como base os discursos escravistas sobre a necessidade de reformar a escravidão e de encontrar soluções ao problema da reprodução da mão da obra cativa após a cessação legal do trafico de africanos escravizados em 1831, este texto desvenda o papel central e o valor simbólico que as "mães escravas" vieram ocupar nos debates políticos mais importantes do Brasil oitocentista. Usando tropos e metáforas da natureza, o discurso escravocrata definiu a função reprodutora das mulheres escravizadas como seu papel “natural" - um papel que também ajudaria a domesticar os "instintos rebeldes" dos escravos masculinos. Este texto argumenta também que dentro desse contexto, proprietários de escravos e juristas enfatizaram a importância do conceito legal partus sequitur ventrem para comunicar a ideia de legalidade da escravidão, precisamente durante o período de crescente deslegitimização da instituição, tanto dentro quanto fora do Brasil.

Palavras chaves: mães escravas, partus sequitur ventrem, reprodução escrava

\section{"Madres esclavas", partus sequitur ventrem, y naturalización de la reproducción esclava en el Brasil del siglo XIX.}

\section{Resumen}

Con base en los discursos esclavistas sobre la necesidad de reformar la esclavitud y de resolver el problema de la reproducción de la mano de obra cautiva después del fin de la trata legal de africanos esclavizados en 1831, este texto demuestra el valor simbólico que las "madres esclavas" fueron a ocupar en los debates más importantes en el Brasil del siglo XIX. Usando tropos y metáforas de la naturaleza, el discurso esclavista definió la función reproductora de las mujeres esclavas como su papel "natural” - un papel que también ayudaría a domesticar los "instintos rebeldes" de los hombres esclavizados. Este texto también mantiene que, dentro de este contexto, propietarios de esclavos y juristas enfatizaron el concepto legal partus sequitur ventrem para comunicar la idea de legalidad de la esclavitud, precisamente durante el periodo de creciente deslegitimización de la institución esclava, tanto dentro cuanto fuera del Brasil.

Palabras claves: madres esclavas, partus sequitur ventrem, reproducción esclava

\section{"Mères esclaves", Partus Sequitur Ventrem, et la naturalisation de la reproduction d'esclaves au Brésil au XIXe siècle}

\section{Résumé}

En examinant les discours des propriétaires d'esclaves à propos des moyens pour remplir les rangs après la suppression légale de la traite africaine, cet article montre l'influence de la reproduction des esclaves pour les débats les plus importants au sujet de l'esclavage et de l'affranchissement au cours du XIXe siècle. A travers les tropes et les métaphores faisant référence à la nature, ce discours a insisté sur la reproduction et les soins maternels comme fonction "naturelle" des esclaves féminines - une fonction qui pouvait simultanément pacifier les esclaves masculins turbulents et rebelles. Cet article démontre aussi que, dans un contexte de valeur symbolique intensifiée de la reproduction des femmes esclaves, les propriétaires d'esclaves et les juristes ont soulignél'importance de la formule partus sequitur ventrem pour communiquer une idée de la légalité de l'esclavage, précisement à l'heure de la délégitimisation, dedans et dehors le Brésil.

Mots clés: mères-esclaves, partus sequitur ventrem, reproduction d'esclaves 
C

onsider the following glimpses into the experience of childbirth for enslaved women living in the hinterlands of the Brazilian Empire during the 1870s. In November 1873, the slave Macária from the village of Santa Ana, province of Ceará, sued her masters José Carneiro da Cunha and his wife Ana Teodora de Menezes for freedom. Through her lawyer Macária argued that her masters "had promised her manumission after she gave them eight children" and that, believing in that promise, she had given birth to nine offspring. By contrast, according to an 1870 report from Ceará's police secretariat, the pregnant slave Delfina, from the district Frade, was on the verge of giving birth when her master Manoel Bento da Costa sent for a midwife to assist her. Instead of waiting, Delfina locked herself into a room where, after delivering her own baby, she proceeded to kill it, and to lock the tiny body into a box, the keys to which she deliberately misplaced. ${ }^{2}$

These snippets into the intimate realities of pregnancy and childbearing provide us with two contrasting visions of the possible meanings of reproduction for enslaved women of African descent in nineteenth-century Brazil. While the slave Macária admitted, or perhaps only emphasized for the purposes of obtaining her freedom, that she gave birth to nine children to become the property of her masters, the slave Delfina did not allow what contemporaries called "the fruit of her womb" to survive. She refused her master the right to possess even the dead body of her baby. Both of these narratives make evident that, whatever other meanings enslaved women assigned to their reproductive lives, a preoccupation with their masters' right to dispose of their children as slave property and instruments of labor could not have been far from their minds. They reveal enslaved women's knowledge of the gendered legal parameters of slave reproduction and awareness that control over childbirth could be an avenue to resist the institution. More importantly, these fragmented stories confront us with the realization that far from being merely a fact of nature, childbirth and reproduction under slavery were conflictive and profoundly marked by the framework under which hereditary slave status was legally transmitted in slaveholding Brazil.

Indeed, both Portuguese civil legislation and post-colonial Brazilian jurists acknowledged the Roman legal principle of partus sequitur ventrem, which established that the legal status of enslaved children followed that of their mothers, as the legal foundation of hereditary enslavement. Perhaps due to the fact that this device appeared to act as the "natural" enforcer of perpetual slavery, or because the population of captives as a whole did not increase naturally in Brazil, the relationship between enslaved women's generative lives and reproductive labor and the reproduction of slavery has not received direct scholarly attention. ${ }^{3}$ It is not that the scholarship on Brazilian slavery has failed

2 Ação de Liberdade, 71, \# 135, in Documentos: Revista do Arquivo Público do Ceará, v. 3, (Fortaleza: Arquivo Público do Estado do Ceará, 2006), p. 85-91; Secr. Pol. Ceará, of. 19 Julho 1870, Cx. Doc. Avulsos, Polícia, Arquivo Público do Estado do Ceará.

${ }^{3}$ Recent studies suggest that some slave populations achieved positive natural growth. See e.g., Klein and Luna, 2010, p. 163-164; Paiva and Libby, 1995, p. 203-33; Gutierrez, 1986, p. 35-52. 
to examine slave reproduction. Demographic studies have demonstrated how sex ratios, fertility rates, and population imbalances were factors influencing the reproduction of captives in various regions. ${ }^{4}$ An important body of work on enslaved women has analyzed the gendered experiences of motherhood, childbearing, family and community formation. ${ }^{5}$ Yet, for the most part, the scholarship has separated the topics of reproduction and motherhood from the study of the labor processes, legal strictures, and matters of property that circumscribed slave life. Some historians have focused on slave reproduction as part of a debate on whether the formation of "slave families" can be seen as proof either of the slaves' ability to resist the oppressive nature of bondage or the masters' power to dominate their human property. ${ }^{6}$ Nevertheless, on the whole, this literature has not interrogated whether the politics of domination over "slave families" included gender-specific forms of subordination of enslaved women and their reproductive bodies. Even more broadly, the scholarship has omitted an analysis of the meanings and uses of female slave reproduction in the definition of slavery itself.

\section{The relationship between enslaved women's generative lives and reproductive labor and the reproduction of slavery has not received direct scholarly attention}

Through an examination of slaveholders', politicians', and jurists' ideas about the functions of female slave reproduction and about the importance of partus sequitur ventrem as the legal principle that justified slavery in post-independence Brazil, this article seeks to shift the ground on which we are accustomed to analyze slave relations, slave reproduction, and the changing definitions of slavery during the nineteenth century. By centering on what historian Jennifer Morgan calls "the impact of women on the development of slavery", I account for some of the discursive processes that naturalized the hereditary captivity of people of African descent during the period of increasing delegitimization of the institution. (Morgan, 2004, p. 4) At the same time, I shed light into some of the representational mechanisms through which the framework of slavery produced a gendered category of "slave mothers" with specific work and social functions, and into the social construction, instead of "natural" assignation of the task of reproducing and stabilizing the slave labor force to female slaves. In focusing on these debates, this essay engages a growing body of scholarship that explores both the symbolic and material significance of enslaved women's reproduction and mothering labor to the perpetuation of the race-based

\footnotetext{
${ }^{4}$ For references to these studies, see Slenes, 1996, n. 10, p. 141-42.

5 See, e.g., Giacomini, 1988; Karasch, 1996; Slenes, 1996.

${ }^{6}$ For a summary of the positions in these debates, see Florentino and Góes, 1997, p. 172-175; Slenes, 1999, p. 48-51; Marquese, 2004, p. 280-282.
} 
slave systems of the Afro-diasporic societies of the Americas. ${ }^{7}$ It also contributes to the recent literature that traces the centrality of ideas and policymaking concerning the bodies and reproductive labor of women of color as Caribbean colonial societies and Brazil faced the process of deconstruction of slavery. ${ }^{8}$

During the nineteenth century, Brazilian slavery expanded from the sugar plantations of Bahia to the agricultural and mining industries of Minas Gerais, São Paulo, and Rio de Janeiro. As Dale Tomich reminds us, bonded labor in Brazil as in the rest of the Americas strengthened and expanded on a massive scale during the "anti-slavery century"- the period between the Haitian Revolution in 1791 and final abolition in Brazil in 1888. This "second slavery", which developed in tandem with the emergent international capitalist division of labor, intensified the use of slave laborers, especially in the areas producing export crops, and more so during the first half of the nineteenth century (Tomich, 2004, p. 56-71). This search to obtain greater productivity from slaveholding enterprises took place as the 1831 legal suppression of the African slave trade and the 1850 final cessation of the illegal traffic made it more difficult to replenish bonded labor through new shipments of slaves. With the end of the Atlantic slave trade, the inter-provincial trade that delivered slaves acquired in the Northeast to the more dynamic sectors of the Brazilian economy in the Southeast increased dramatically. Moreover, since the inauguration of the Empire in 1822 and into the mid-nineteenth century, the contradictions between the establishment of a liberal constitutional order and the continuous enslavement of people of African descent, including the hundreds of thousands of africanos livres - Africans illegally held captive since 1831 - became increasingly apparent. By the mid-1860s, mounting international pressure, massive exodus from the plantations, and internal anti-slavery mobilization, including an increasing number of male-slave-led rebellions, led to the first legislative steps towards emancipation. A proposal centered on the "emancipation of the womb", authored by the influential jurist and politician Agostinho Marques Perdigão Malheiro, was officially endorsed by Pedro II as the most practical means to end slavery in a controlled and peaceful manner. This conservative proposal, a modified version of which became the "free womb" law passed by Parliament in 1871, did provide for the freedom of children subsequently born of enslaved women, while it forced those children to serve their mothers' masters until age twenty-one, and deferred complete emancipation to a later date. (Pena, 2001, p. 279-295)

It is my contention that, within this controversial context, female slave reproduction and the legal principle of partus sequitur ventrem became centerpieces in the debate regarding the perpetuation of slavery since the legal end of the African slave trade in 1831. Elite planters concerned with the replenishment of captive laborers and resolved to maximize profits from the existing population of slaves, regarded enslaved women's generative lives and mothering labor as

7 Davis, 1971; Bush, 1990; Brown, 1996; Gaspar and Hine, 1996; White, 1999; Morgan, 2004; Wood, 2013. ${ }^{8}$ See, e.g., Barros, 2014; Otovo, 2016. 
central to the procreation of a creole population of slaves that would replace African captives imported in the trade. At the same time, continuous concerns with slave rebellion and fears of the outpouring of "barbarian" African men through the illegal traffic intensified the symbolic value of enslaved women as preventatives of social unrest among enslaved men. The centrality of enslaved women's reproduction to the perpetuation of slavery is also evident in slave owners' and jurists' deployment of the principle partus sequitur ventrem as the ultimate legal justification of the continuous right of slaveholders to possess human property and their descendants. But, if enslaved women's reproductive capacities were at the heart of an argument that legitimized hereditary slavery, they were also central for those who devised a gradual and controlled means to end slavery. In particular, Perdigão Malheiro - a legal scholar who also represented the slaveholding class - elaborated an abolitionist argument that hinged on the demonstration that partus sequitur ventrem provided the juridical ordering of the practice of enslavement in order to advocate for its legal reversal. Through a discourse of gender that overlaid the natural reproductive functions of the female body and the mothering labor of enslaved women with legal meanings, Perdigão Malheiro envisioned an indirect path towards emancipation. This gendered path, embodied on the free-womb law, provided that slaves, like women and children, "naturally" submitted to the authority and slow legislative action of male jurists, lawyers, and ultimately, the state, while they remained as human property.

\section{“Slave Mothers", Rebellious Men, and the Naturalization of Slave Reproduction}

Intellectuals and politicians who played a role in securing Brazil's independence in 1822 elaborated a discordant discourse in opposition to slavery as they attempted to reconcile the contradictions between the practice of slavery and the liberal ideals that in many ways shaped the break with Portugal and the establishment of the Empire. Since early on in the life of the new nation, members of this intelligentsia proposed to reform slave relations to make them more compatible with a modern, post-independence, capitalist world, and placed a series of expectations of the generative power and reproductive labor of bonded women at the center of their projects. Here we can begin by analyzing João Severiano Maciel da Costa's ideas, presented in 1821. An intellectual from the "generation of independence", da Costa saw the adoption of liberalism as the best approach to achieve economic development and parity with the modern European nations. In accordance to liberal ideals and to the aspirations of forging a post-colonial national order, da Costa opposed African slavery. He argued that the continuous transference of African slaves to Brazilian territory challenged national unity, threatened the ethnic integrity of the nation, and slowed down economic modernization. Using what in the surface appears as gender-neutral language that, in fact, masked a gender-specific fear 
of the rebellious potential of African men, da Costa warned that the "hoards" of black African slaves, "barbarian from birth and education, who had no legal personality or property", and who became "enemies of the whites" due to their own condition, could represent a serious danger. Evoking the horrors of Saint Domingue as a "catastrophe caused by slaves", this intellectual cautioned that a sudden internal rebellion undertaken by a "powerful and foreign enemy" living within Brazil's own borders and stimulated by ideas of freedom could bring the nascent Empire to its knees. Employing military-like descriptions that conveyed the masculine threat represented by African captives, da Costa emphasized that it would be nearly impossible to mount an effective resistance against the "barbarism and ferociousness" of the foreign slaves (Costa, 1988, p. 20-22).

Like other early nineteenth-century liberal politicians and intellectuals, da Costa argued that to avert the potential for slave rebellion and to end all the other problems caused by slavery it was necessary to end the African slave trade. ${ }^{9}$ Nevertheless, he did not call for immediate emancipation. Reflecting the interests of slaveholders, some of whom were also political leaders, he envisioned slow measures that would only gradually end slavery and replace it with a contingent of disciplined free laborers, both domestic and foreign. Thus, he proposed that after ending the African traffic, Brazil should first reproduce its own captive population and generate "a great, beautiful creole population" through slave breeding - a strategy that relied on the labor of enslaved women as reproducers, caretakers, and stabilizers of the slave labor force. To accomplish this, he argued that it was necessary to promote marriages among slaves. Ordering slaveholding establishments upon conjugal units of men and women was indispensable, given that "licentiousness prevents natural reproduction, causes venereal diseases, disrupts discipline, and brings many other evil consequences". Even more, da Costa maintained that slaveholders "made a mistake in not enslaving equal numbers of women and men, given that female slaves were needed to treat men, educate children, take care of the elderly, and provide hospital services". Evoking and naturalizing a socially-constructed notion of the functions of enslaved women as mothers and caretakers of children who were their slaveholders' property, da Costa called planters to "release [enslaved] mothers from long and difficult labor, or provide a number of female slaves to take care of the children [born of female slaves] ", so that Brazil as a whole would stop "losing a generation of creole slaves to death in the cradle and early childhood" (Costa, 1988, p. 36-37).

The legal end of the African slave trade in 1831 prompted a renewed reflection on the most effective ways to use and reproduce the existing slave labor force. During the 1830s plantation owners and slaveholders began to publish manuals for agricultural enterprises, offering recommendations on labor-saving techniques, discipline, and the most efficient methods to plant, harvest and produce agricultural crops, especially sugar and coffee, with the use of bonded labor. (Marquese, 2004, p. 267-278) Crucially, enslaved women's reproductive

${ }^{9}$ See e.g., Andrada e Silva, 1988, p. 78. 
roles, their sexuality, and their nurturing labor were central to the planters' projects of modernization of the agricultural establishments. Thus, for instance, the politician and planter Miguel Calmon du Pin e Almeida argued in his Ensaio sobre o fabrico do açúcar, published in 1834, that given that the African slave trade ended it was necessary to preserve the life of the existing slaves and promote their reproduction. For this, masters needed to offer better treatment to their captives by providing better food, clothing, shelter, and care in time of disease, and by applying mild forms of punishment. Just as important, Pin e Almeida called planters to motivate "slaves to marry a female partner of their own" [my emphasis]. In this planter's view, the promotion of marriages was a matter of morality and also of practical interest, because in this way slaves would be able to reproduce naturally and provide the long-term labor that their masters expected of them. (Almeida, 1834, p. 59-60, 65)

One of the most widely distributed planter manuals, Carlos Augusto Taunay's Manual do agricultor brasileiro, first published in 1839, also demonstrates slaveholders' expectations about the role of enslaved women in regenerating the slave population. For Taunay, slave reproduction along with strict discipline based on fear and other slave management techniques, was to raise the international competitiveness of the Brazilian slaveholding agricultural economy. As a way to combat the effects of the high rates of slave mortality and arguing that even if it was not desirable that the "African race" should reproduce itself to the point of substituting the "white race", Taunay argued that it was in the masters' best interest to take advantage of and stimulate the natural reproduction of their captives. By balancing the number of male and female slaves in the establishments, and enforcing strict discipline, Taunay maintained, it would be possible for masters to conserve a complete slave labor force without too many purchases of new captives. To achieve this, it was not necessary for slave owners to force their slaves to reproduce or to constitute legally sanctified marriages. Instead, masters should simply not interfere with the "natural tendency of the sexes to join themselves". While slave quarters should be segregated by sex, and married or coupled captives should live in their respective quarters, Taunay recommended, slaves "should be able to spend time with their wives on Sundays" and at night [my emphasis]. The Manual also offered advice on the care of pregnant slaves so that they could perform the functions of mothers or caretakers of newborn children destined to be slaves as well as on the practices of breastfeeding and rearing of enslaved babies (Taunay, 1839, p. 78-81).

The allocation of care of newborn enslaved babies as a labor task of mothering female slaves is also presented in Francisco Peixoto de Lacerda Werneck's Memória sobre a fundação de uma fazenda na província do Rio de Janeiro, first published in 1847. Here, the author expressed a concern that both the negative returns in slaves' services compared to their high prices and the high mortality of captives caused losses and even bankruptcies among many slave owners. Even though the coffee industry from the Southeast greatly prospered after the 1831 official ban on the African slave trade, by the late 1840s the high costs of 
acquiring slaves in the unlawful market had begun to persuade at least some coffee growers of the need to find alternative sources for the replenishment of their slave labor. The advice of assigning enslaved women with newborn babies such supposedly "lighter" tasks as washing clothes instead of field labor indicates that, at least for Lacerda Werneck, slaveholders could alleviate some of their preoccupations by charging their female slaves with childrearing tasks that would ensure the survival of enslaved babies and thus provide better returns on slaveholders' investments. Lacerda Werneck even counseled that enslaved women who had given birth could return to their usual labor only after one year, and that they should leave their babies in care of other female slaves who would then bathe, change, and feed all the infants in the establishment (Conrad, 1972, p. 23,48; Werneck, 1847, p. 63-64).

\section{Female slave reproduction and the legal principle of partus sequitur ventrem became centerpieces in the debate regarding the perpetuation of slavery}

By far, the most elaborate advise on the "special attention" that enslaved women needed to facilitate procreation and mothering is included in Antonio Caetano da Fonseca's Manual do agricultor dos gêneros alimentícios, published in 1863. Written by a priest and planter as a guidebook for the production of foodstuffs, the Manual recommended different labor tasks, work schedules, and exposure to the elements for enslaved women during their menstruation and pregnant months. Arguing that all female slaves should be assigned lighter work loads due to their "weaker constitutions", Father Caetano da Fonseca cautioned that exposing pregnant slaves and those in their periods to rigorous labor, cold water and fire and sun could cause miscarriages, uterine bleeding or suppression of their menses. Instead, he recommended that these bondswomen should perform field labor until ten in the morning and after three in the afternoon, and domestic service. During parturition, the Father counseled, female captives "deserve the same attention that their mistresses receive and their babies the same care of that of their young masters" (Fonseca, 1864, p. 98-99). Such careful consideration of the treatment of enslaved women during their reproductive years indicates an intensified expectation of their reproductive potential and mothering labor after the final cessation of the illegal slave trade in 1850. While the internal slave trade supplied especially coffee growers from the Southeast with captives imported from the Northeast, planters from other regions and even from Rio de Janeiro, São Paulo and Minas Gerais complained of "labor shortages" that pointed to increasing prices and difficulties in the access to slave labor. In this context, as a deputy from Maranhão stated 
in 1856, it is likely that planters "set all [their] hopes on the wonders of procreation of [their] enslaved women"10 (Conrad, 1872, p. 32).

Caetano da Fonseca's Manual also presents a slaveholder's perspective on how the formation of stable unions among slaves, in addition to replenishing the slave labor force, could foster discipline among male slaves - two tasks that depended on the reproductive bodies, sexuality, and nurturing labor of female slaves. According to the Father, the small number of marriages among slaves was the main cause for the decrease of "the African race" in slaveholding establishments, after other factors such as unhealthy living conditions, excessive labor, and lack of attention to slaves' diseases. Thus, he reminded slaveholders that since "their slaves are men, and like other men they have propensities towards love", they should facilitate their slaves' marriages. In this view, marriage would bring peace and morality to the slaves and profits and tranquility to the masters. The reasons for this were that "the married male slave ordinarily has children, and he must love them, as well as his wife; therefore, he would be more attached to his master's house. And if the master treats his children well, he elicits love from the slave, due to retribution of sympathy." As a result, the Father argued, "the male slave would not go outside at night, or disturb neighboring families and because of that get into any kind of trouble" [my emphasis throughout]. Beyond these advantages, Caetano da Fonseca noted that the children of slaves would bring wealth to their masters. The Father also made explicit that the benefits of marriage relied on the sexual services of female slaves, since he warned that married slaves should not live in the same quarters with single slaves; instead, "married slaves should have their own quarters and they should receive their women at night" (Fonseca, 1864, p. 102).

Agricultural manuals penned by plantation owners were not unique to Brazil. During the nineteenth century, plantation owners in the United States' South also produced manuals - often published in the periodical press - that prescribed standardized slave management techniques. Like their Brazilian counterparts, some of them - including James Hammond's 1857-58 manual - recommended specific practices to facilitate female slave reproduction and breastfeeding. As Rafael de Bivar Marquese argues, plantation owners both in Brazil and the United States' South understood slave administration within a logic of paternalistic duty (Marquese, 2004, p. 254-56). Yet, it is clear that the Brazilian plantation owners were concerned with the provision of labor after the legal end of the African trade in 1831. Consequently, they envisioned a central role for enslaved women as "mothers" and "natural" reproducers of the future slave labor force. This role included expectations about women's childbearing capacities as well as gendered claims upon the mothering labor spent in feeding, caring for, and raising children who were property and instruments of labor for the slaveholders. The centrality of enslaved women's reproductive roles as presented in agricultural manuals demonstrates that the appropriation of enslaved women's generative lives could not have been far from the

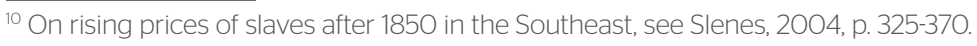


calculations of slave owners, regardless of whether or not Brazil's slave population as whole achieved natural increase or systematic "slave breeding" policies were ever in place. Even more, the disruptions in the availability of slave laborers after the 1850 end of the illegal African trade intensified the masters' expectations of the reproductive potential of their female slaves. Nevertheless, elite planters did not conceptualize enslaved women's generative power and mothering labor as useful only for the regeneration of the slave labor force. As we have seen, expectations of enslaved women's roles included serving as preventatives against social unrest. Through their sexual services and procreation, enslaved women were expected to mollify unruly, immoral, and "ferocious" male slaves.

But why did slaveholders seek the stabilizing effects of enslaved women's sexuality and reproduction? Through an examination of the same agricultural manuals analyzed here, Marquese convincingly argues that a concern with both the replenishment of the labor force after the legal end of the slave trade and fear of slave rebellion informed elite planters' emphasis on increasing slaves' potential for reproduction and establishing effective means of social control in the plantations. Thus, they proposed the strict enforcement of discipline, recognition and stimulation of "slave families" and other strategies to create a type of "peasant ethic" among slaves. These would both diminish the potential for uprisings and increase the slave labor force (Marquese, 2004, p. 296-298). Yet, what is missing in this argument is an analysis of the gendered implications in both the planters' paternalist attempts to foster the creation of "slave families" and in their fears of slave rebellion. By contrast, this analysis of planter manuals highlights that, even though on the surface slaveholders' descriptions appear to refer to a gender-neutral category of slaves, slave owners perceived male slaves as volatile, sexually unrestrained, and uncivilized, and therefore capable of making trouble. Likewise, underneath politicians and planters' calls for the formation of "slave families", it is possible to observe their expectations that enslaved women's sexuality and reproductive labor would be used in the cause of taming unruly male slaves. Even more, slaveholders conceptualized slave families as hetero-normative units that reproduced power asymmetries between men and women and a sexual division of labor according to which female slaves were in charge of reproducing and mothering tasks.

In all likelihood, slaveholders' preoccupation with the restlessness of male slaves was linked to a fear of the many slave uprisings and rebellions that enslaved men led during the tumultuous decades of the 1820s and 1830s and again the 1850 s and 1860s. Even though, much of the historiography on slave rebellion in Imperial Brazil has ignored gender, some studies present details of the roles of leadership that African and Brazilian bondsmen played in slave uprisings. For instance, the leaders of the slave rebellions that swept Bahia during the 1820s and 1830s - years characterized by the institutional breakdowns and divisions surrounding independence and the creation of a post-colonial order - were African-born male slaves, runaways, and freedmen (Reis, 1992, p. 32-33). The 
leaders of the 1835 Malê uprising in Bahia - one of the most effective urban slave rebellions of the early Imperial period - were African male slaves, mostly single, who occupied positions of political-religious leadership in the Muslim community of Salvador (Reis, 1993, p. 139-159). The majority of the leaders of the slave uprisings that caused "fear and terror" among slave owners in the counties of Carrancas, Minas Gerais and Vassouras, Rio de Janeiro during the 1830s were African bondsmen who collaborated with creole male slaves. The leaders of slave rebellions that took place after the end of the illegal traffic in 1850 in São Paulo, Minas Gerais, Rio de Janeiro and Maranhão were mostly creole bondsmen (Andrade, 1999, p. 48-52; Gomes, 1995, p. 219-228). Yet, even in cases when Brazilian-born male slaves led slave insurrections, they often drew on African cultural traditions to develop their identity politics and tools of resistance (Slenes, 2008, p. 235-242).

Scholars have noted that the many slave uprisings of the first decades of post-colonial life generated nearly hysterical fears of African-born slaves and freedmen and anxieties about their potential to organize collective action of small or greater magnitude. Yet this fear appears to have had a gendered character. For instance, after witnessing the many insurrections led by African male slaves in Bahia, Minas Gerais and Rio de Janeiro during the 1830s, Brazilian elites and authorities regarded them as "dangerous guests", disloyal "outsiders" and "barbarians, desperate in slavery", ready to "invade villages and plantations" (Reis, 1992, p. 108-109, 118-121 and 1993, p. 200-201; Andrade, 1999, p. 65-67; Gomes, 1996, p. 43-46). The imperial government even ordered local police forces from the areas surrounding the city of Rio de Janeiro to compile a list with complete information on "all the men of color from their districts". Furthermore, the slaveholding class worried that a rebellion in the mold of the Haitian Revolution - a revolution that relied on the conscription and militarized participation of substantial numbers of men - would threaten the entire slaveholding system and the security of the state. While it is true that some politicians might have deployed the specter of the Haitian Revolution for their own political purposes, it is also clear that slaveholders and authorities perceived the massive importation of Africans as enslaved laborers as saddled with a permanent threat of slave rebellion, whether of large or small scale (Gomes, 1995, p. 258-280; Reis, 1996, p. 28-29 and 1992, p. 118).

This fear of the rebelliousness, restlessness, and savagery on the part of African-born male slaves was probably also compounded by the higher numbers of African men who entered Brazilian ports as slaves. According to estimates, 65 percent of all Africans shipped as slaves during the Transatlantic trade were male (Klein and Luna, 2010, p. 162). This number might have been slightly higher during the period between 1830 and 1850, when an estimated 68.8 percent of African disembarking slaves were male. ${ }^{11}$ As Sidney Chalhoub

"The estimate for the period between 1830 and 1850 was calculated from a total of 550,102 slaves disembarked, which is a fraction of the total of slaves that arrived in Brazil. See http://www.slavevoyages.org/ tast/database/search.faces, accessed on Dec 17, 2013 
demonstrates, the demographic increase of Africans among the slave population during the 1840s and 1850s went hand in hand with anxieties that the "Africanization" of the slave labor force would inevitably lead to slave insurrection (Chalhoub, 2012, p. 127-128). Fears of the action of "foreign" men in destabilizing the slaveholding system appeared to have achieve fever pitch during the investigations on the 1848 slave conspiracy in Vassouras and Valenças, Rio de Janeiro. Authorities uncovered rumors that "free African" men, enslaved men and secret British agents were planning a slave rebellion of massive proportions. Indeed, as Slenes shows, the gravity of the situation was such that Minister Eusebio de Queiroz, who presided over the passing of the 1850 law that ended the unlawful African trade, qualified this conspiracy as an engine in turning public opinion in favor of finally banning the costly and dangerous illegal traffic of slaves (Slenes, 2012, p. 112-113).

It is in this context in which politicians and slaveholders determined to reform the institution of slavery proposed the use of enslaved women's sexual and reproductive lives and mothering labor to create hetero-normative "slave families" and in this manner domesticate threatening African or Africanized male slaves. Indeed, this discourse emphasized the idea that, through their sexual and reproductive capacities and labor, enslaved women had the ability to render volatile enslaved men docile and restrained. Furthermore, according to this discourse, the unions of enslaved women and African male slaves, coupled with strict discipline, would result in the creation of "a great, beautiful generation of creole slaves" - a Brazilian-born captive population that would be docile, submissive, and deferential to their masters. This discourse, relying as it did on gender signifiers that appealed to nature - including descriptions of enslaved women as nurturers and caretakers and references to the "natural" tendencies of the sexes to join themselves and procreate - contributed to make the reproduction of slavery through hereditary means appear "natural". The same discourse also qualified the labor of enslaved women in raising children who remained the property of their masters as the "natural" tasks that women as mothers performed for their offspring. In this way, the symbolic value of enslaved women's reproduction became tied to the rhythms of the African slave trade, to the projects of reform of slave relations and to the volatile environment of slavery in the Empire during the first five decades of its existence.

\section{On Partus Sequitur Ventrem}

An examination of the juridical language that planters and jurists used to excuse hereditary slavery during this period reveals that the concern with the matter of slave reproduction after the end of the trade helped shape a legal discourse focused on the validity of the ancient Roman notion of partus sequitur ventrem. Legislation on slavery in post-colonial Brazil came from a variety of sources and was complex - a matter that was confounded by the fact that the newly created Empire did not elaborate its own civil code. Thus, the Criminal Code, 
Imperial non-codified decrees, and even provincial and municipal ordinances regulated slave relations. Even more, in absence of a civil code, Brazilian judges and courts recognized both codified and non-codified Portuguese civil legislation enacted until 1821 as statutes with "force of law", as well as Roman law, which was considered as subsidiary to Portuguese civil law.

\section{Politicians and slaveholders determined to reform the institution of slavery proposed the use of enslaved women's sexual and reproductive lives and mothering labor}

The Roman principle of partus sequitur ventrem had a longstanding tradition in Portuguese America and Brazil. Yet, it was precisely when the hereditary reproduction of slavery through enslaved women's bodies became a focal point of debate that slaveholders deployed this notion as the fundamental validation of the right of slave owners to hold people of African descent and their offspring as human property. Thus, for instance, in his Manual, Taunay admitted that "it is more difficult to justify the enslavement of creoles than that of their parents purchased in the [African] Coast". Nevertheless, he appealed to a link between nature and law by invoking birth and arguing that "the status of the child follows that of the mother, filius ventris sequitur". Furthermore, adopting a naturalizing language that linked the biological needs of newborns to this Roman law, he argued that "this principle is based on the need that babies have of their mothers' milk and of their masters' bread in order to survive. The law judges that masters would not take charge of the litter or make disbursements throughout their long years of childhood if they did not take into account the labors they will provide during the rest of their lives". Thus, Taunay concluded, "the vow of the law legitimizes the right of the masters" (Taunay, 1839, p. 78).

Legal scholars concerned with structuring the laws on slavery and with presenting legal justifications of slavery even in the face of the nation's liberal ideology also centered on partus sequitur ventrem as the foundational principle of hereditary enslavement, as attested in Lourenço Trigo de Loreiro's civil law compendium Instituições do direito civil brasileiro. Originally from Portugal, Trigo de Loreiro was a lawyer and professor at the Olinda School of Law and a member of the Provincial Assembly of Pernamubuco (Blake, 1902, p. 236327). In his compendium, Trigo de Loreiro stated that, "among us, those who are born of the slave womb are born slaves of the owner of the womb, except in some cases, as noted in Roman law". He explained that the principle of partus sequitur ventrem "was received in Portugal along with Roman law, even though the laws of the Visigoths allowed masters of the female and male slaves to allocate among themselves the fruits born of both of them" (Loreiro, 1864, p. 33-35). This is a reference to a disposition on the division of slave property mandated 
in the Visigothic Code (compiled and published in 654) in the following manner: "As a son is born of both parents, why should he follow the condition of his mother, while he owes his being equally to his father. It is, therefore, but reasonable that we decree that where one slave has married a slave owned by another person, any offspring of said marriage shall belong equally to the masters of both slaves". ${ }^{2}$ Trigo de Loreiro's Instituições continued describing that "this principle [of partus sequitur ventrem] survived and still remains among us as a more reasonable one than the second one" (Loreiro, 1864, p. 33-35). Although the perpetuation of racial slavery through the female line has often been made to appear as a timeless practice, this legal explanation makes clear that the assignation as slaves of a particular master to the children of enslaved women was one possible legal arrangement among others.

If Trigo de Loreiro allowed that Portuguese and Brazilian legislators selected partus sequitur ventrem as the principle to mandate the hereditary transmission of slavery, Perdigão Malheiro in his A escravidão no Brasil stated that this legal device was responsible for the "propagation of slavery in the world since its beginning days until our times". As soon as any society introduced slavery, he continued, "that doctrine followed them like a shadow to the body, became inseparable, and in this way, perpetuated slavery" (Malheiro, 1866, v. 2, p. 130). Such an ahistorical assertion is uncharacteristic of the work of the famous jurist who was not only a lawyer of the Council of State, but also a legal scholar, who as a member and president of the Instituto dos Advogados do Brasil (Brazilian Institute of Lawyers) between 1861 and 1866, and member of Parliament between 1869 and 1872, helped shape some of the most significant debates about slavery and emancipation during the 1850s and 1860s (Pena, 2001, p. 253-338). Perdigão Malheiro in fact conceived A escravidão no Brasil as an historical account of Brazilian slavery, both Indigenous and African, since the colonial period into the 1860s, and as a treaty on the changing legal doctrines - Roman, Portuguese and Brazilian - that regulated enslavement, manumission and the rights of libertos, or freedmen and women. However, the intention of the author in producing this work was not simply academic. He sought to systematize the existing laws on slavery and freedom, given the confusing state of the Brazilian legislation, to present a discussion of the urgent need of emancipation and to propose a specific plan towards the gradual and controlled abolition of slavery (Malheiro, 1866, v. 1, p. 13-14). As the recent scholarship on Perdigão Malheiro has shown, this emancipationist position - one that maintained that abolition could only come through legislative action - is key to understand the book's arguments and approach to history and its representations of the laws regulating slavery and freedom. For the jurist, the institution of slavery did not have legitimacy from the perspective of natural law, which established the right of individuals to freedom. Instead, it was positive, human law that tolerated slavery. Thus, A escravidão no Brasil seeks to demonstrate how legislation in Ancient

12 The Visigothic Code: Forum judicum, Book X. Tit. I, Sec. xvii, p. 5, The Library of Iberian Resources Online, http://libro.uca.edu/vcode/bk10.htm, accessed Feb 14, 2014. 
Rome, Portugal and Brazil "acquiesced to the facts of slaveholding" and recognized the rights of masters to enslave humans and turn them into property, with the purpose of maintaining public order. ${ }^{13}$

In tracing the ways in which the decrees that provided the legal foundation of slavery changed according to different practices of enslavement, Perdigão Malheiro began by arguing that ancient Roman slavery "found its excuse" in the recognition of the right of winners to enslave the defeated parties in international wars. As he moved to a discussion of slavery in "our" past legislation, he pointed out that Portuguese legal tradition allowed the enslavement of war enemies, but that none of those instances had any application in current law. Instead, he argued, "the slavery that exists and is maintained among us", which he also noted was unsustainable, "sprung from a proscribed foundation, (the violence of ripping Africans away from their lands in order to enslave them for profit)." Once African slavery was introduced in Brazil, he maintained, it was through "the principle of partus sequitur ventrem, or in other words, the principle of perpetuity and heredity of slavery, which affects indefinitely all the descendants of enslaved women, even if the father is free", that slavery reproduced itself. After the end of the "proscribed" African slave trade, the jurist further noted, "our current laws are left only with birth as the foundation of slavery" (Malheiro, 1866, v. 1, p. 50). This argumentation demonstrates that after the prohibition of slave imports and in the absence of a civil code, jurists, like slave owners, kept alive Roman concepts of slavery, and particularly partus sequitur ventrem to transmit a notion of the legality of slavery and the right of slaveholders to hold human property.

Perdigão Malheiro's emphasis on the longevity of partus sequitur ventrem as the foundation of slavery served another political purpose. As several scholars have demonstrated, Perdigão Malheiro interpreted Roman and Portuguese legislation with the intention of establishing a particular tradition of jurisprudence that justified gradual legal action and legislation as the only measures capable of ending slavery (Pena, 2001, p. 256-257; Chalhoub, 1990, p. 36-37; Lara, 2000, p. 45). In this sense, Perdigão Malheiro's abolitionist project hinged on the demonstration that the Roman principle partus sequitur ventrem provided the juridical ordering of the practice of enslavement in Imperial Brazil. His proposal emphasized that the only possible approach to extinguish slavery in Brazil was to attack it at its "very root" which was birth. Thus, he called for a legal "emancipation of the womb", that would declare the freedom of all the children born of enslaved women on a set date. This, he argued, would once and for all bring justice and revoke "that odious and unjustifiable barbarian principle", the "infamous partus sequitur ventrem". Perdigão Malheiro's plan proposed that the children of enslaved women should stay with their mothers and under the care of their masters, who would "raise and educate them

Here, I follow the analysis presented by a body of recent scholarship that situates Perdigão Malheiro and $A$ escravidão no Brasil in its historical context and examines how this work both reflected and shaped debates on slavery and emancipation during the nineteenth century. See Pena, 2001, p. 256-572; Chalhoub, 1990, p. 36-37, 128-130, 140-142 and 2003, p. 139-155, 164-182; Lara, 2000, p. 39-47. 
in exchange of their free services" until the age of twenty-one (Malheiro, 1866, v. 2, p. 206-208).

If Perdigão Malheiro needed to keep alive a legal tradition that justified the transmission of slave status through women's bodies in order to advocate for its legal reversal, the emphasis on partus sequitur ventrem and its gendered symbolism also served to represent Afro-descendant slaves as passive and in need of the redemption that could only be offered by the paternalist action of elite male lawyers and legislators. Here, the jurist emphasized the increasing benevolence, especially of lawyers and magistrates, who had already facilitated the "humanitarian and Christian progress of Brazilian society" towards slaves. He cited the recommendations that judges received on "taking the side of freedom" on behalf of slaves in freedom suits, the practice of providing lawyers to slaves engaged in lawsuits and the frequent manumissions granted for "gratitude" towards slaves as examples of the benignity of Brazilian slaveholding society. In fact, Perdigão Malheiro asserted that since the end of the African slave trade in 1850, slaveholders had become more interested in the care of their slaves, abstaining from cruel punishments and providing them with better clothing, lodging, and even lands, so that slaves could raise their own families. He mentioned the kindness of many slave mistresses who raised the children of their female captives as their own. Yet, justice, humanity, Christian principles, and social and economic reasons all demanded to put an end to the "revolting and unjust enslavement of blacks and their descendants". In making a case for the adoption of free-womb legislation, the author of A escravidão no Brasil inquired: "Who that has seen the birth of the unfortunate child of a slave womb has not asked himself (...) innocent creature, what sin did you commit so that you and all your descendants are condemned to the degrading and odious condition of a slave?" (Malheiro, 1866, v. 2, p. 94-95, 114-123, 130-132).

Despite the urgent need of bringing freedom to child-like and feminized slaves, Perdigão Malheiro argued that immediate emancipation was inadmissible. His abolitionist proposal cautioned that it would not be prudent to even fix a particular date for the emancipation of all the remaining slaves by the time that free-womb legislation would be adopted. This, he warned, would bring the disorganization of labor and would interfere in the production that brought most wealth to the country. Even more, he presaged that immediate emancipation would disrupt the peace of families, and would threaten public order and ultimately the state, as thousands of slaves would be "unleashed" from the "domestic subjection that contains them" (Malheiro, 1866, v. 2, p. 202, 206). ${ }^{14}$ It is not surprising that in his historical depiction of slavery, Perdigão Malheiro characterized quilombos, or the communities where decidedly un-child-like slaves took matters of freedom into their own hands, as a "menace for civilized people and as cradles of barbarism among slaves". Arguing that the largest of the maroon communities in colonial history, the quilombo of Palmares had produced "immense and constant danger", the author of A escravidão no

${ }^{14}$ On the conditions of enslavement during the time of emancipation, see Butler, 2011. 
Brasil emphasized its size (18,000 to 20,000 inhabitants), its fortifications and its masculinized military might (Malheiro, 1866, v. 2, p 32, 34). Thus, to avoid these severe problems to slaveholders, to the Brazilian state and to "the slaves themselves", Perdigão Malheiro called for a series of indirect measures that would facilitate a gradual and controlled emancipation while improving the living conditions of the remaining slaves. Among them were the recognition of the right of slaves to their pecúlio (personal liberation fund), the facilitation of the manumission of slaves through self-purchase and the granting of freedom to slaves who had been abandoned by their masters and to those who had provided "extraordinary services of great significance" (Malheiro, 1866, v. 2, p. 215-222).

Devising a controlled legal path for emancipation became a matter of urgency for the government, and for the Emperor himself, during the 1860s. Politicians and slave owners acknowledged the need to reform and even end slavery, as they observed the crumbling of the slave system in the United States, which left Brazil and Cuba isolated as the last remaining slaveholding nations in the Americas. The deepening diplomatic crisis between England and Brazil regarding the de-facto slavery of the africanos livres - a crisis that culminated in the 1863 break of diplomatic relations between the two countries - also added pressure to end the slaveholding system (Conrad, 1972, p. 70-76; Pena, 2001, p. 277-286). Just as important, slave rebellions, which appeared more and more menacing to slaveholders and authorities during the 1850s and 1860s, threatened the institution of slavery with increasing urgency. As we have seen, those decades witnessed frequent male-slave-led insurrections and the formation of quilombos not only in the Southeast but also in far-away provinces such as Maranhão, Mato Grosso and Pernambuco (Reis, 1996, p. 18; Queiroz, 1977, p. 180-81; Gomes, 1996, p. 42-44).

This context of fear that the increasing restlessness of slaves will bring anarchy and a threat to the peace of families and the state is essential to understand Perdigão Malheiro's contention that gradual abolition could only begin through the emancipation of the children subsequently born to female slaves. Much of the scholarship on abolition has argued that the reasons behind the adoption of free-womb legislation were the sanctioning of historical precedent, as other countries in the Americas had passed similar laws in the early nineteenth century, or the recognition that to end slavery, it was necessary to eliminate the last source for its renewal (Cowling, 2013, p. 55-56; Conrad, 1972, p. 90-91; Abreu, 1996, p. 574-575). Nevertheless, it is highly likely that gendered assumptions about slave rebellion and about the perceived stabilizing effects of enslaved women's sexual and reproductive lives and labor also shaped politicians' and legal scholars' recommendation of this particular solution to the "slave question". ${ }^{15}$ In Perdigão Malheiro's view, "emancipation of the womb" would not

\footnotetext{
15 Programs of gradual emancipation through free womb laws were first enacted in the emergent Spanish American republics of Chile (1811), Argentina (1813), Gran Colombia (1821), and Uruguay (1825) within a context of armed mobilization of enslaved men during the wars of independence. These laws were used either as concessions or as rewards for enslaved men's military service. See Andrews, 2004, p. 61-65.
} 
only free the children subsequently born of enslaved women, but would also "create less hostile relations between masters and slaves". The reason for this was that "paternal, and above all, maternal love is such that slaves resign themselves to their sad condition as long as their children can be free; their highest ambition is the freedom of their children" [my emphasis] (Malheiro, 1866, v. 2, p. 211). From this perspective, enslaved women as "mothers" would function as a tool for the pacification of rebellious and restless adult slaves in a context where slaveholders would continue to retain rights of dominion and property over their captives.

\section{Despite the urgent need of bringing freedom to child-like and feminized slaves, Perdigão Malheiro argued that immediate emancipation was inadmissible}

Thus, Perdigão Malheiro made the long-standing validity of partus sequitur ventrem and also the naturalized tie between enslaved mothers and their children the cornerstones of his proposal for a juridical emancipation that began with the free womb and continued only through controlled and indirect measures. Appealing to a gendered understanding about the reproductive functions and mothering labors of enslaved women, this proposal envisioned an orderly paternalist society in which slaves, like women and children, "naturally" submitted to male authority. As Pena argues, Perdigão Malheiro's non-threatening, legal path to end slavery would offer an assurance to slaveholders that paternalist relations of power and the right to hold the remaining Afro-descendants as property would not end, at least not in the foreseeable future, and that the "tranquility and peace" of the state would not be threatened. This conservative abolitionism reflected Perdigão Malheiro's position as a lawyer, jurist and parliamentarian who represented the interests of slaveholders from the south of Minas Gerais, the planters as a group, and perhaps even the Emperor himself, given his intimate connections with Pedro II. His proposal, then, would serve as a tool to gain adherents for gradual emancipation, even among the slaveholding class, while attempting to slow down the actual fulfillment of abolition, by preventing the radicalization of the emancipation process (Pena, 2001, p. 273-294).

\section{Conclusions}

An important body of scholarship on gender and emancipation in Brazil has focused on the ways in which "slave mothers" manipulated gendered discourses that emphasized the link between enslaved women and reproduction in order to strive for manumission for themselves and their children during the late nineteenth century (Cowling, 2014; Abreu, 1996; Graham, 1991; Kittelson, 
2005). In this essay, I shift attention to the discourses on slavery that emerged since 1831 and that, in fact, created and naturalized a category of "slave mothers". In this way, I seek to illuminate the centrality of female slave reproduction to the restructuring of slave relations and to the redefinition of slavery itself during this period. Thus, I have argued that the changing dynamics of the slave trade, the projects of reform of slave relations, and the growing international and domestic pressure for emancipation shaped specific webs of expectations about enslaved women's reproduction, sexuality, childbirth and childcare among slaveholders and politicians linked with the most profitable sectors of the slaveholding economy. Concerns with the replenishment of the bonded population after the prohibition of slave imports and fears of slave insurrection in face of an increasing number of male-slave-led armed rebellions shaped a discourse that centered on enslaved women as reproducers of the slave labor force and appeasers of an unruly population of captives. Indeed, the symbolic value of enslaved women as mothers, caregivers, and nurturers of new generations of slaves became a centerpiece in the debate on the perpetuation of slavery though hereditary means. This discourse relied on gender signifiers that appealed to nature to establish a link between the generative potential and mothering labor of enslaved women and the offspring they birthed to be the property of their masters. In doing so, the discourse produced a naturalized category of "slave mothers".

This essay has also shown that after the legal end of the slave trade in 1831 and within a context of intensified symbolic value of female slave reproduction, the ancient Roman notion of partus sequitur ventrem acquired renewed legal significance. Slaveholders and jurists, in particular Perdigão Malheiro, kept alive the legal principle that imposed a biological - and thus naturalized - link between the status of an enslaved woman and her offspring to communicate a notion of the legality of slavery, even in face of the increasing opposition that the institution confronted within and outside Brazil. The emphasis on the legality of partus sequitur ventrem also became magnified as Perdigão Malheiro elaborated a proposal for a gradual, controlled, and legal process of abolition that began with the emancipation of children subsequently born to female slaves. Emancipation through "free womb" laws and other legislation would ensure an orderly and slow transition towards final abolition, one in which enslaved adults - like women and children - waited passively for the benevolent action of a paternalist state. 


\section{Bibliographical references}

ABREU, Martha. Slave Mothers: Emancipation and Female Space in Debates on the 'Free Womb' Law, 1871. Journal of Latin American Studies, vol. 28, n. 3, p. 567-80, Oct. 1996 ALMEIDA, Miguel Calmon Du Pin e. Ensaio sobre o fabrico do açúcar ( $1^{\text {st }}$ ed., 1834) OLIVEIRA, Waldir Freitas (Org.) Salvador: Federação das Indústrias do Estado da Bahia, 2002

ANDRADE, Marcos Ferreira de. Rebelião escrava na comarca do Rio das Mortes, Minas Gerais: o caso Carrancas. Afro-Asia, vol. 21-22, p. 48-52, 1998-1999

ANDREWS, George Reid. Afro-Latin America, 1800-2000. New York: Oxford Press, 2004

BARROS, Juanita de. Reproducing the British Caribbean: Sex, Gender, and Population Politics after Slavery. Chapel Hill: University of North Carolina Press, 2014

BLAKE, Augusto Victorino Alves Sacramento. Diccionario Bibliographico Brazileiro, vol. 7. Rio de Janeiro: Imprensa Nacional, 1902

BROWN, Kathleen. Good Wives, Nasty Wenches and Anxious Patriarchs: Gender, Race, and Power in Colonial Virginia. Chapel Hill: University of North Carolina Press, 1996

BUSH, Barbara. Slave Women in Caribbean Society, 1650-1838. Bloomington: Indiana University Press, 1990

BUTLER, Kim. Slavery in the Age of Emancipation: Victims and Rebels in Brazil's Late $19^{\text {th }}$-Century Domestic Trade. Journal of Black Studies, vol. 42, n. 6, p. 968-92, set. 2011.

CHALHOUB, Sidney. Visões da liberdade: uma história das últimas décadas da escravidão na Corte. São Paulo: Companhia das Letras, 1990

Machado de Assis, Historiador. São Paulo: Companhia das Letras, 2003

A força da escravidão: Ilegalidade e costume no Brasil oitocentista. São Paulo: Companhia das Letras, 2012

CONRAD, Robert. The Destruction of Brazilian Slavery, 1850-1888. Berkeley: University of California Press, 1972

COSTA, João Severiano Maciel da. Memória sobre a necessidade de abolir a introdução dos escravos africanos no Brasil. In SALGADO, Graça (Int.) Memórias sobre a escravidão. Rio de Janeiro: Arquivo Nacional Fundação Petronio Portella, 1988, p. 12-47

COWLING, Camillia. Conceiving Freedom: Women of Color, Gender and the Abolition of Slavery in Havana and Rio de Janeiro. Chapel Hill: University of North Carolina Press, 2014

DAVIS, Angela. Reflections on the Black Woman's Role in the Community of Slaves. In The Angela Y. Davis Reader. Malden: Blackwell Publishing, 1998, p. 11-126

FLORENTINO, Manolo and GOES, José Roberto. A paz das senzalas: Famílias escravas e tráfico atlântico, Rio de Janeiro, c. 1790-c.1850. Rio de Janeiro: Civilização Brasileira, 1997

FONSECA, Padre Antônio Caetano. Manual do agricultor dos gêneros alimentícios. Rio de Janeiro: Eduardo \& Henrique Laemmert, 1864

GIACOMINI, Sonia Maria. Mulher e escrava: Uma introdução histórica ao estudo da mulher negra no Brasil. Petrópolis: Vozes, 1988

GOMES, Flávio dos Santos. Histórias de quilombolas: Mocambos e comunidades de senzalas no Rio de Janeiro, século XIX. Rio de Janeiro: Arquivo Nacional, 1995

Em torno dos bumerangues: outras histórias de mocambos na Amazônia colonial. Revista USP, vol. 28, p. 42-44, Dez-Fev 1995/1996

GRAHAM, Sandra. Slavery's Impasse: Slave Prostitutes, Small-Time Mistresses, and the Brazilian Law of 1871. Comparative Studies in Society and History. vol 33, n. 4, p. 669-694, 1991

GUTIERREZ, Horacio. A Harmonia dos Sexos: Elementos da estrutura demográfica da população escrava do Paraná, 1800-1830. Anais do V Encontro Nacional de Estudos Populacionais, $A P E B$, p. 35-52, 1986

HAMMOND, James. Plantation Manual, 1857-58. James Hammond Papers (container 43). Manuscript Division, Library of Congress, LC-MS-24695-1

KARASCH, Mary. Slave Women on the Brazilian Frontier in the Nineteenth Century. In GASPAR, David and HINE, Darlene Clark (Eds.) More than Chattel: Black Women and Slavery in the Americas. Bloomington: Indiana University Press, 1996, p. 79-96

KITTELSON, Robert. Women and Notions of Womanhood in Brazilian Abolitionism. In SCULLY, Pamela and PATTON, Diana (Eds.) Gender and Emancipation in the Atlantic World. Durham: Duke University Press, 2005, p. 99-120 
KLEIN, Herbert and LUNA, Francisco Vidal. Slavery in Brazil. New York: Cambridge University Press, 2010

LARA, Sílvia H. Legislação sobre escravos africanos na América Portuguesa. Madrid: Fundação Tavera, 2000

LOREIRO, Trigo de. Instituições de Direito Civil Brasileiro. $3^{\mathrm{a}}$ ed., vol, 1. Recife: Typographia Universal, 1864

MALHEIRO, Agostinho Marques Perdigão. A escravidão no Brasil: Ensaio histórico-jurídico-social. 2 vols. Rio de Janeiro: Tipografia Nacional, 1866

MARQUESE, Rafael de Bivar. Feitores do corpo, missionários da mente: Senhores, letrados e o controle dos escravos nas Américas. São Paulo: Companhia das Letras, 2004

MORGAN, Jennifer. Laboring Women: Gender and Reproduction in New World Slavery. Philadelphia: University of Pennsylvania Press, 2004

OTOVO, Okezi. Progressive Mothers, Better Babies: Race, Public Health and the State in Brazil, 1850-1945. Austin: University of Texas Press, 2016.

PAIVA, Clotilde Andrade and LIBBY, Douglas. Caminhos alternativos: Escravidão e reprodução em Minas Gerais. Estudos Econômicos, vol. 25, n. 2, p. 203-33, Mayo-Agosto, 1995

PENA, Eduardo Spiller. Pajens da Casa Imperial: jurisconsultos, escravidão e a lei de 1871. Campinas: Editora da Unicamp, 2001.

QUEIROZ, Suely Reis de. Escravidão negra em São Paulo. Rio de Janeiro: José Olympio, 1977 REIS, João José Reis. Recôncavo rebelde: Revoltas escravas nos engenhos baianos. Afro-Asia vol. 15, p. 100-126, April, 1992

. Slave Rebellion in Brazil: The Muslim Uprising of 1835 in Bahia. Trans. Arthur Brakel. Baltimore: Johns Hopkins University Press, 1993

. Quilombos e revoltas escravas no Brasil. Revista USP, vol. 28 p. 14-39, Dez-Fev 1995/1996

SILVA, José Bonifácio Andrada e. "Representação à Assembleia Geral Constituinte e Legislativa do Império do Brasil sobre a escravatura”. In SALGADO, Graça (Intr.) Memórias sobre a escravidão. Rio de Janeiro: Arquivo Nacional Fundação Petronio Portella, 1988, p. 61-78

SLENES, Robert W. Black Homes, White Homilies: Perceptions of the Slave Family and of Slave Women in Nineteenth-Century Brazil. In GASPAR, David and HINE, Darlene Clark (Eds.) More than Chattel: Black Women and Slavery in the Americas. Bloomington: Indiana University Press, 1996, p. 126-146

. Na senzala uma flor: Esperanças e recordações na formação da família escrava - Brasil sudeste, século XIX. Rio de Janeiro: Editora Nova Fronteira, 1999

. The Brazilian Internal Slave Trade, 1850-1888: Regional Economies, Slave Experience, and the Politics of a Peculiar Market. In JOHNSON, Walter (Ed.) The Chattel Principle: Internal Slave Trade in the Americas. New Haven: Yale University Press, 2004, p. 325-370

. Saint Anthony at the Crossroads in Kongo and Brazil: 'Creolization' and Identity Politics in the Black South Atlantic, ca. 1700-1850. In SANSONE, Livio, SOUMONNI, Elisee and CARRY Boubacar (Eds.) Africa, Brazil and the Construction of Trans-Atlantic Black Identities. Trenton, N.J.: Africa World Press, 2008, p. 209-254

. A 'Great Arch' Descending: Manumission Rates, Subaltern Social Mobility, and the Identities of Enslaved, Freeborn, and Freed Blacks in Southeastern Brazil, 1791-1888. In GLEDHILL, John and SCHELL, Patience (Eds.) New Approaches to Resistance in Brazil and Mexico (Durham: Duke University Press, 2012), p. 112-113

TAUNAY, Carlos Augusto. Manual do agricultor brasileiro ( $1^{\text {st }}$ ed. 1839). MARQUESE, Rafael de Bivar (Org.) São Paulo: Companhia das Letras, 2001

TOMICH, Dale. Through the Prism of Slavery: Labor, Capital and World Economy. Lanham: Rowman \& Littlefield Publishers, Inc., 2004

WERNECK, Francisco Peixoto de Lacerda. Memória sobre a fundação de uma fazenda na província do Rio de Janeiro (1 ${ }^{\text {st }}$ ed., 1847). SILVA, Eduardo (Org.) Brasília: Senado Federal/Fundação Casa de Rui Barbosa, 1985

WHITE, Deborah Gray. Ar'n't I a Woman?: Female Slaves in the Plantation South. New York: Norton \& Norton, 1999

WOOD, Marcus. Black Milk: Imagining Slavery in the Visual Cultures of Brazil and America. Oxford: Oxford University Press, 2013 